\title{
Article \\ Monitoring the Sediment Surface Elevation Change across a Chronosequence of Restored Stands of Tropical Mangroves and Their Contemporary Carbon Sequestration in Soil Pool
}

\author{
Jose Alan Castillo ${ }^{1, * \mathbb{D}}$, Richard MacKenzie ${ }^{2}$, John Rommel Manahan ${ }^{1}$ and Judith Castillo ${ }^{3}$ \\ 1 Ecosystems Research and Development Bureau, Department of Environment and Natural Resources, Forestry \\ Campus, Los Baños 4031, Philippines; jrmanahan0412@gmail.com \\ 2 Institute of Pacific Islands Forestry, USDA Forest Service, Hilo, HI 96721, USA; richard.mackenzie@usda.gov \\ 3 Forestry Development Center, University of the Philippines Los Baños, Los Baños 4031, Philippines; \\ jfcastillo2@up.edu.ph \\ * Correspondence: allan536@yahoo.com
}

check for

updates

Citation: Castillo, J.A.; MacKenzie,

R.; Manahan, J.R.; Castillo, J.

Monitoring the Sediment Surface

Elevation Change across a

Chronosequence of Restored Stands of Tropical Mangroves and Their

Contemporary Carbon Sequestration in Soil Pool. Forests 2022, 13, 241.

https://doi.org/10.3390/f13020241

Academic Editor:

Bradley B. Walters

Received: 1 January 2022

Accepted: 3 February 2022

Published: 4 February 2022

Publisher's Note: MDPI stays neutral with regard to jurisdictional claims in published maps and institutional affiliations.

Copyright: (c) 2022 by the authors. Licensee MDPI, Basel, Switzerland. This article is an open access article distributed under the terms and conditions of the Creative Commons Attribution (CC BY) license (https:// creativecommons.org/licenses/by/ $4.0 /)$.

\begin{abstract}
Over the past 30 years, 30-40\% of the world's mangroves have been lost and continue to be lost to deforestation. In recent years, mangrove rehabilitation projects have increased, replacing once natural and diverse mangrove forests with monotypic stands (e.g., Rhizophora mucronata). However, the vulnerability to sea level rise of these artificial stands and their effectiveness at providing ecosystem services is unclear. To address these gaps, we compared the rate of sediment surface elevation change and contemporary soil $C$ sequestration across three differently aged mangrove plantations $(5,10,25$ years) in relation to a natural mangrove forest in Quezon province, Philippines using rod surface elevation tables (rSETs) and soil C analyses. Over a 3-year period, we found that the elevation of the 5-year-old plantation had the highest rate $\left(6.12 \mathrm{~mm}^{-1} \mathrm{ear}^{-1}\right)$, followed by 10 -yearold $\left(1.70 \mathrm{~mm}\right.$ year $\left.^{-1}\right)$ and 25 -year-old $\left(0.16 \mathrm{~mm}\right.$ year $\left.^{-1}\right)$ plantations, while the natural stand had a decreasing rate $\left(-1.9 \mathrm{~mm}_{\text {year }}{ }^{-1}\right)$. In addition, the mean soil carbon contemporary sequestration rate was 226,123 , and $8.9 \mathrm{~g} \mathrm{C} \mathrm{m}^{-2}$ year ${ }^{-1}$ for the 5-, 10-, and 25-year-old plantations. Old mangroves have bigger carbon stocks, whereas young mangrove plantations are more resilient to SLR and have higher contemporary carbon sequestration rates. Except for biomass and basal area, we found no correlation of the sediment elevation change and soil $\mathrm{C}$ sequestration rates with other stand variables. Apart from the 5-year-old plantations, the rates of sediment elevation change obtained are less than the global (3.2 mm year ${ }^{-1}$ ) and local (2-4 $\left.\mathrm{mm}_{\text {year }}{ }^{-1}\right)$ rates of sea level rise (SLR). These suggest that most of the forested coastal wetlands studied are not keeping pace with SLR and may potentially drown if there is no available land behind them to retreat. This also indicates that pro-active solutions such as strict protection must be made.
\end{abstract}

Keywords: mangroves; rod surface elevation table; accelerated sea level rise; contemporary soil carbon sequestration; Philippines

\section{Introduction}

Mangrove forests provide many ecosystem services to people throughout the tropics. At the local scale, mangrove forests provide habitat for fish, shrimps, and crabs that are important food resources, materials for house poles and roof thatching, and protection from intense wave action during tsunamis and typhoons [1-3]. On a global level, the high levels of productivity, coupled with water-logged and anoxic sediment conditions, result in massive stores of above- and below-ground carbon stocks that could potentially mitigate increased atmospheric $\mathrm{CO}_{2}$ levels [4-7].

While nearly $30-40 \%$ of the world's mangroves have been lost over the past 30 years and continue to be lost to deforestation, there has been an increase in mangrove rehabilitation projects, especially in the tropical Southeast Asia. Mangrove restoration/rehabilitation 
projects typically involved replacing once natural and diverse mangrove forests with monotypic stands of mangroves (e.g., Rhizophora mucronata) [8,9]. However, it is unclear how effective these restored mangrove ecosystems are at providing similar levels of ecosystem services as the natural systems they once were.

With the onset of climate change and global warming, accelerated sea level rise (SLR) remains one of the major future threats to the survival of mangrove forests and projects on mangrove forest rehabilitation. Sea level rise has nearly doubled since 1990 at a rate of $3.2 \mathrm{~mm} \mathrm{year}^{-1}$ [10] and it is predicted to increase by 75-190 cm by year 2100 [11]. Mangroves need to maintain their forest floor elevation relative to sea level through the combined action of sediment accretion and below-ground productivity in order to survive and not drown. This then begs the question of how vulnerable tropical mangroves, both in natural stands and in plantations, are to rising sea levels.

The vulnerability of mangroves to SLR can be assessed through the measurement of mangroves' sediment surface elevation change using the rod surface elevation table technique. The rod surface elevation table (rSET) is a tool developed to measure surface elevation and subsurface processes contributing to coastal wetland surface elevation change [12,13]. While the mangroves in the Asia-Pacific region are being studied and monitored for their vulnerability to SLR using the rSET technique [13-17], there is currently a lack of rSET data from the Philippines on rates of surface elevation change. This is despite the fact that the Philippines is one of the top 15 countries with the largest mangrove forest cover in the world [18]. Furthermore, few studies have been conducted that have compared surface elevation change between restored and natural mangroves.

Quantifying the surface elevation, sediment accumulation, and contemporary soil C accumulation rates of restored mangroves in relation to natural stands will improve our knowledge and inform policy makers on how resilient/vulnerable these different types of mangroves are to rising sea levels, and how effective restored mangroves function in terms of carbon storage compared to natural ecosystems $[13,19]$. Determining how fast mangrove forest floors are rising relative to SLR will also help us identify mangrove forests that may be more resilient (i.e., keeping with SLR), are sequestering carbon at a faster rate, and require special conservation designation. This is in contrast with the less productive mangrove forests that may require a more pro-active restoration and management action. It will also allow us to examine how tree density, diversity, and other stand structure variables influence sedimentation rates and contemporary soil $\mathrm{C}$ accumulation rates in mangroves.

To address the above gaps, this study aims to: (1) quantify the rate of sediment surface elevation change across three differently chrono-ages mangrove plantations and a natural mangrove using rSETs; (2) quantify the contemporary soil C sequestration rates across the chrono-ages mangrove plantations; and (3) determine the influence of tree density, diversity, biomass, basal area, and soil $\mathrm{C}$ stocks on the rates of sediment elevation change and contemporary soil $C$ sequestration of mangrove plantations and natural mangroves.

This study is one of the first to monitor the vulnerability of Philippine mangroves to SLR by monitoring the changes in sediment surface elevation of mangroves in response to rising sea levels across a chronosequence of mangrove plantations and a reference natural mangrove. Here, we seek to answer the following research questions: (1) In relation to natural stands, do chrono- ages mangrove plantations have similar rates of sediment elevation change and soil $C$ sequestration rates? and (2) What vegetation and soil variables (tree density, diversity, biomass, basal area, and soil C density) correlate with these rates?

\section{Methods}

\subsection{Study Site}

The study sites are located in the towns of Pagbilao and Catanauan in Quezon province, some 150 and $251 \mathrm{~km}$, respectively, south of Manila, the Philippines' capital (Figure 1). Three mangrove plantations that were 5,10 , and 25 years old, as well as a reference natural stand that was greater than 100 years old, were selected for the study (Figure 1). The 5-year-old mangrove plantation study site $\left(13.5794^{\circ} \mathrm{E}\right.$ and $\left.122.2751^{\circ} \mathrm{E}\right)$ was composed of 
Rhizophora stylosa with sediments being a sandy-loam substrate and having a pH of 6.8. The 10-year-old mangrove plantation stand was dominated by Rhizophora apiculata with sediments being a sandy-loam substrate and having a $\mathrm{pH}$ of 5.4. The 25-year-old mangrove plantation $\left(13.5789^{\circ} \mathrm{E}\right.$ and $\left.122.2749^{\circ} \mathrm{E}\right)$ was dominated by mature individuals of Rhizophora stylosa with sediments being a loam substrate and having a $\mathrm{pH}$ of 6.3 . All of the plantations were located in Barangay Matandang Sabang Kanluran, Catanauan, Quezon and the plots are all located in the seaward portion of the stands.

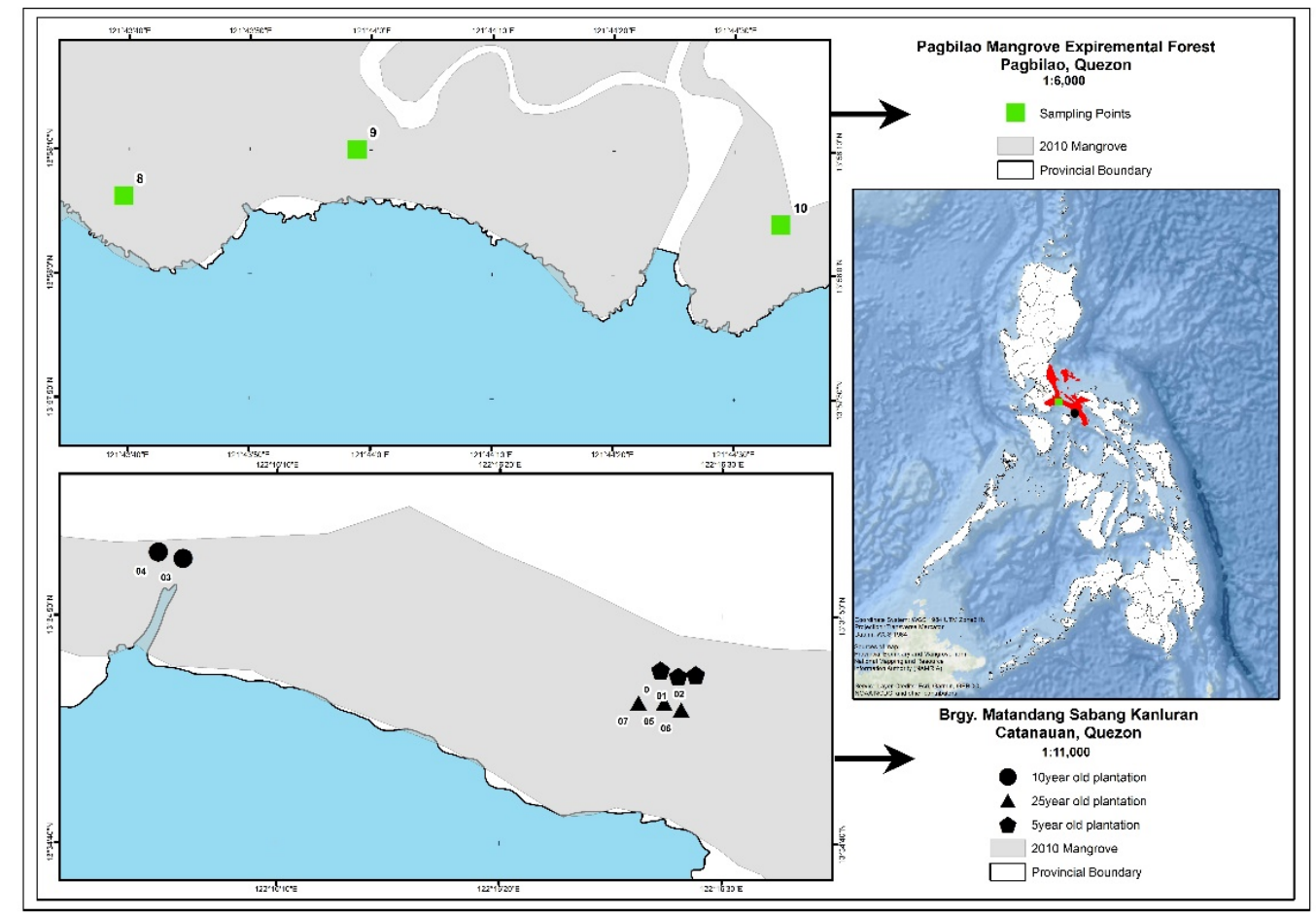

Figure 1. Study sites in Pagbilao and Catanauan, Quezon province, Philippines.

Located some $105 \mathrm{~km}$ from the mangrove plantations, the reference natural mangrove stand is located inside the protected Pagbilao Mangrove Experimental Forest (PMEF) located in Barangay Ibabang Palsabangon, Pagbilao, Quezon. PMEF is the largest remaining natural mangrove forest nearest to Manila. Albeit located in a different embayment, PMEF is the closest natural mangrove stand to the three chrono-aged mangrove plantations in Catanauan. PMEF is a 145 ha natural mangrove forest being managed by the government. The study site $\left(13.9685^{\circ} \mathrm{E}\right.$ and $\left.121.7337^{\circ} \mathrm{E}\right)$ in PMEF was specifically located at the seaward portion of the mangrove forest and was dominated by mature individuals of Sonneratia alba, Avicennia marina, and Aegiceras floridum. The sediments were a sandy-loam substrate with a $\mathrm{pH}$ of 4.2 .

\subsection{Characterization of Stand Variables}

We haphazardly created three $7 \mathrm{~m}$ radius plots within each forest type for a total of 12 plots (Figure 1). Within each plot, all trees $>5 \mathrm{~cm}$ in diameter at breast height (dbh) were identified to species and dbh measured to the nearest $0.1 \mathrm{~cm}$. Trees $<5 \mathrm{~cm} \mathrm{dbh} \mathrm{(e.g.,}$ saplings) were identified to species and dbh measured within a $2 \mathrm{~m}$ radius circular plot nested within the larger $7 \mathrm{~m}$ radius subplot. Tree density, species richness, biomass, and carbon (C) stocks (above-ground and below-ground) were then quantified [20,21]. Density refers to the total number of individuals in a plot, while species richness refers to the number of species per plot. 
To determine biomass $\left(\mathrm{kg} \mathrm{ha}^{-1}\right)$, equations developed by Komiyama et al. [22] for above-ground and below-ground biomass of mangroves from samples taken from selected Southeast Asian countries were used. The biomass equations take the following form:

$$
\begin{aligned}
& \text { Above-ground biomass }(\mathrm{kg})=0.251 p \mathrm{dbh}^{2.46} \\
& \text { Below-ground biomass }(\mathrm{kg})=0.199 p^{0.899} \mathrm{dbh}^{2.22}
\end{aligned}
$$

where $\mathrm{W}=$ biomass, $p=$ wood density, $\mathrm{dbh}=$ diameter at breast height in $\mathrm{cm}$. Mangrove wood density values were taken from Howard et al. [20] and Kauffman and Donato [21]. The AGB and BGB data were converted to their $C$ stock equivalent using a $C$ fraction of $48 \%$ and $39 \%$, respectively, as suggested by Kauffman and Donato [21] and adapted by Adame et al. [23], Kauffman et al. [24,25], and Castillo et al. [26] for mangroves.

Basal area per plot $\left(\mathrm{m}^{2} \mathrm{ha}^{-1}\right)$ was computed per tree using the following formula:

$$
B A=\frac{\pi \times\left(\frac{D B H}{2}\right)^{2}}{10,000}
$$

Basal area for each tree was then summed up in each plot and divided by the plot area.

For soil C stock estimation, soil measurements, collection, and analyses were conducted in each of the plots, following the method of Kauffman and Donato [21]. In each plot, a soil core was taken from an undisturbed spot nearest the center by carefully inserting a $5.5 \mathrm{~cm}$ diameter open-face peat gouge auger to a depth of $200 \mathrm{~cm}$. Each core was divided into depth intervals of $0-15,15-30,30-50,50-100$, and $>100 \mathrm{~cm}$ if parent materials (marine sand/sediment or rock) were not encountered before the depth of $100 \mathrm{~cm}$. A $5 \mathrm{~cm}$ sample was taken in the middle of each layer, stored in a labelled container, and brought to the laboratory for oven drying and analysis. In each plot, soil depth to parent material was measured three times near the center by driving a graduated aluminum rod until refusal. The rod was $300 \mathrm{~cm}$ in length, which was the inference limit of the study.

Samples were brought to the soil laboratory of the USFS IPIF in Hawaii, oven-dried to a constant weight at $60{ }^{\circ} \mathrm{C}$ and weighed to the nearest $0.1 \mathrm{~g}$ for bulk density (BD) determination. Dried samples were ground into a fine powder using a mortar and pestle or a Wiley ${ }^{\mathrm{TM}}$ mill and then sieved through a $2 \mathrm{~mm}$ mesh sieve to remove any large roots, rocks, or shell fragments. A homogenized sample from each sediment interval was then analyzed for total C using a Costech ${ }^{\mathrm{TM}}$ elemental analyzer (Costech Analytical Technologies, Valencia, CA, USA) at the University of Hawaii at Hilo Analytical Lab. Soil C density $\left(\mathrm{MgC} \mathrm{ha}^{-1}\right)$ per depth interval was computed as the product of BD $\left(\mathrm{g} \mathrm{cm}^{3}\right)$, depth interval $(\mathrm{cm})$, and $\% \mathrm{C}$ content, which were added together to obtain the total soil C stock per site, following Kauffman and Donato [21]. BD $\left(\mathrm{g} \mathrm{cm}^{-3}\right)$ was computed as the ratio of the dry weight $(\mathrm{g})$ of the soil sample over its fresh volume $\left(\mathrm{cm}^{-3}\right)$.

The species richness, tree density, and dominant species of the study mangrove stands are summarized in Table 1.

Table 1. Summary table of species richness, tree density, and dominant species per age.

\begin{tabular}{cccc}
\hline Study Site & Species Richness & $\begin{array}{c}\text { Tree Density } \\
\text { (\# of Individuals) }\end{array}$ & Dominant Species \\
\hline $\begin{array}{c}\text { 5-year-old plantation } \\
\text { 10-year-old plantation }\end{array}$ & 1 & 20 & Rhizophora stylosa \\
25-year-old plantation & 4 & 12 & $\begin{array}{c}\text { Rhizophora apiculata } \\
\text { Rhizophora stylosa } \\
\text { Avicennia marina } \\
\text { Natural Stand }\end{array}$ \\
& 6 & 12 & $\begin{array}{c}\text { Sonneratia alba } \\
\text { Aegiceras floridum }\end{array}$ \\
\hline
\end{tabular}




\subsection{Measurement of Sediment Surface Elevation Change Using a Deep rSET}

Deep rSETs (referred to as rSETs from hereon) measure changes in the forest floor elevation over time relative to a fixed substratum. A series of $15 \mathrm{~mm}$ diameter, $1.2 \mathrm{~m}$ long stainless-steel benchmark rods were driven through peat, roots, and other organic matter with a demolition hammer until they: (1) hit refusal (e.g., volcanic basalt), (2) 20 rods were installed, or (3) rod installation was occurring at a rate slower than $10 \mathrm{~s} / 10 \mathrm{~cm}$ of rod length. An rSET receiver was then bolted to the top of the rod and backfilled with concrete. Changes in forest floor elevation were then measured over time by attaching an rSET arm to the rSET receiver and carefully sliding 9 fiberglass pins through the 9 holes on the arm until the bottom of the pins were resting on the sediment surface. The distance from the top of the pin to the top of the arm was then measured over time to provide an estimate of surface gain or loss. Measurements were taken in four different set directions determined during the first measurement, for a total of 36 measurements from each plot at each time point [27].

Deep rSETs were installed in each of the three permanent mangrove monitoring plots established in natural, 5-, 10-, and 25-year-old mangrove plantations. Each mangrove forest type was installed with three rSET plots for a total of 12 rSET plots. Portable wooden platforms were set in the area during each measurement to minimize perturbations to the mangrove sediments. Measurements of surface elevation change were undertaken quarterly after the baseline measurement in September 2015. The rate of sediment surface elevation change $\left(\mathrm{mm}\right.$ year $\left.{ }^{-1}\right)$ for each mangrove forest was computed as slope of the time-series of sediment surface elevation change and time [15]. Due to absence of a local supply of feldspar, we were not able to pair the rSET with marker horizons, so accretion rates could not be measured.

The depths $(\mathrm{m})$ of benchmark rods installed in the study sites for the rSET study are summarized below (Table 2).

Table 2. Summary of benchmark rod depths (m).

\begin{tabular}{cccc}
\hline Location & $\begin{array}{c}\text { Plot 1 } \\
(\mathbf{m})\end{array}$ & $\begin{array}{c}\text { Plot 2 } \\
(\mathbf{m})\end{array}$ & $\begin{array}{c}\text { Plot 3 } \\
(\mathbf{m})\end{array}$ \\
\hline 5-year-old plantation (Catanauan, Quezon) & 11.77 & 5.65 & 3.04 \\
10-year-old plantation (Catanauan, Quezon) & 7.62 & 18.35 & 8.89 \\
25-year-old plantation (Catanauan, Quezon) & 13.57 & 10.63 & 15.14 \\
Natural Stand (Pagbilao, Quezon) & 10.98 & 12.28 & 15.71 \\
\hline
\end{tabular}

\subsection{Contemporary Soil C Sequestration Rate}

The contemporary soil $\mathrm{C}$ sequestration rate $\left(\mathrm{g} \mathrm{C} \mathrm{m}^{-2}\right.$ year $\left.^{-1}\right)$ for each mangrove forest was computed using the method of Lovelock et al. 2014 [13]. This was undertaken by multiplying the dry bulk density $\left(\mathrm{g} \mathrm{cm}^{-3}\right)$ and $\% C$ of the upper $5 \mathrm{~cm}$ of the sediment from each plot with the rate of sediment surface elevation change $\left(\mathrm{mm}^{\mathrm{year}}{ }^{-1}\right)$ from that plot. We chose the top $5 \mathrm{~cm}$ of the core as it typically represents more than 1 year of sediment deposition or 5-50 years of accumulation [13].

\subsection{Statistical Analysis}

The data were tested for normality and homogeneity of variance using the ShapiroWilk test and Levene's test, respectively. Linear regression was used to determine the linear trend in rates of sediment elevation change and soil $C$ sequestration across mangrove ages. The relationship between the rates of sediment elevation change and vegetation variables, as well between the soil $C$ sequestration rates and vegetation variables, were assessed using correlation analysis. Statistical analyses were run using Real Statistics Resource Pack Software Release 5.4 (Zaiontz 2018) and R Statistical Software version 3.5. 


\section{Results and Discussion}

\subsection{Rates of Sediment Surface Elevation Change}

After three years of data collection, the mean rate of sediment elevation change was $6.1 \pm 2.5,1.7 \pm 1.3$, and $0.2 \pm 2.5 \mathrm{~mm}$ year $^{-1}$ for the 5-, 10-, and 25-year-old mangrove plantations, respectively (Table 3, Figure 2). The higher rates observed in the younger aged, restored sites were attributed in part to a higher root growth rate often observed in younger trees compared to older mangrove trees [28-30]. This would have resulted in greater accumulation of below-ground biomass, an important mechanism that allows mangroves to maintain their forest floor and pace SLR [12]. Higher rates in younger sites could also have been attributed to the higher stand stem densities also observed in these sites, though see the discussion below. This would have also increased below-ground productivity as well as increased the structural complexity of the mangrove forest floor and increased the ability of younger forests to trap and retain sediments [31].

Table 3. Summary of mean rates of sediment elevation change (mean \pm SE) of the study sites.

\begin{tabular}{cc}
\hline Stand Age & Mean Rate $\left(\mathbf{m m ~ y e a r}^{-\mathbf{1}}\right)$ \\
\hline 5-year-old & $6.1 \pm 2.5 \mathrm{a}$ \\
10-year-old & $1.7 \pm 1.3 \mathrm{a}$ \\
25-year-old & $0.2 \pm 2.5 \mathrm{a}$ \\
Natural Stand & $-1.9 \pm 0.7 \mathrm{a}$
\end{tabular}

Negative elevation change rate indicates loss in elevation over time. Different letters after the means indicate significant differences at $p<0.05$.

Compared to the restoration sites, our natural reference stand had a declining trend of $-1.9 \pm 0.7 \mathrm{~mm}$ year $^{-1}$ over the study period. In the case of PMEF plots, the loss in sediment elevation could be due more to the tidal position of the plots, which are all located in the seaward portion of the intertidal zone that are regularly exposed to wave action. This is evidenced by an active erosion and toppling of mangrove trees (Avicennia marina and Sonneratia alba) along the PMEF water edge seaward of the plots due to higher wave action in the area, especially during the northeast monsoon. Other studies have also reported decrease in sedimentation and below-ground productivity with forest age $[32,33]$ and negative rates for natural stands, especially for fringing mangroves, as reported in Micronesia [34]. The plots for mangrove plantations in Catanauan were more in the interior portion of the intertidal zone. The highly variable data and few replicates $(n=3)$ per age group could have been the reasons for the statistical non-significance between the means despite the data transformation.

The results of the study suggest that a decreasing trend in sediment elevation change can be observed as mangroves grow older and probably approximate the rate of a natural stand (100 years old) when the mangroves are more than 25 years old.

The rate of sediment elevation change we reported here for the natural mangrove of Pagbilao $(-1.9 \mathrm{~mm} /$ year) is within the global range reported in the literature for natural mangroves (-5.8 to $6.3 \mathrm{~mm} /$ year) [29]. The rate is similar to the lower end of the range ( -3.7 to $4.1 \mathrm{~mm} /$ year) reported in the Caribbean [35]. Negative rates were also reported for Micronesian natural mangroves ( -5.8 to $-0.6 \mathrm{~mm} /$ year), especially the fringing mangroves [34], similar to our seaward plots for natural mangrove in PMEF.

For our chrono-ages mangrove plantations (range: 0.2 to $6.1 \mathrm{~mm} /$ year), the rates are lower than the range reported for created mangroves in Tampa Bay, Florida (4.2 to $11 \mathrm{~mm} /$ year) [29]. However, the rates for mangrove plantations we reported here are within the range of values reported for natural mangroves in Moreton Bay, Australia (0.41-7.05 $\mathrm{mm}$ year $\left.^{-1}\right)$ [13], but lower than the value from southern China at $9.6 \mathrm{~mm}$ year $^{-1}$ [14]. This is probably due to differences in sediment supply and wave action, which can reduce the rate by eroding sediments, and other physical factors such as typhoons that hit the area that can cause tree mortality and, later on, peat collapse $[16,36]$. 


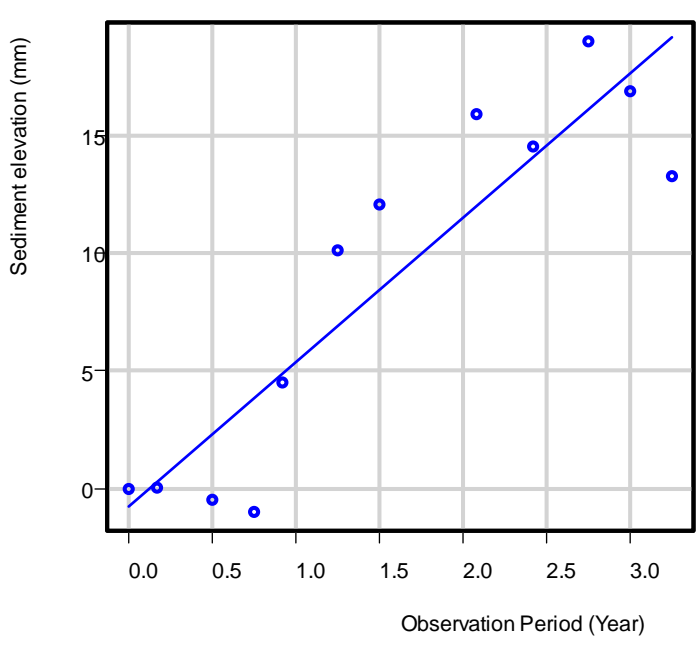

(a) 5-year-old

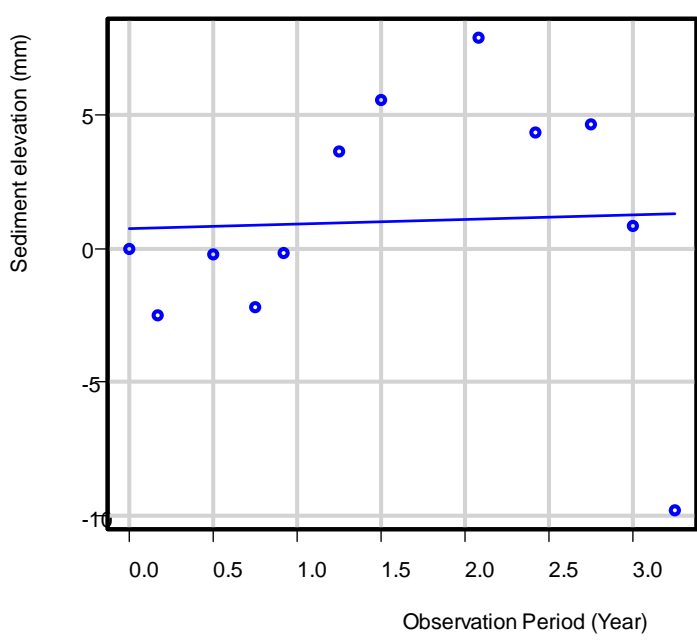

(c) 25-year-old

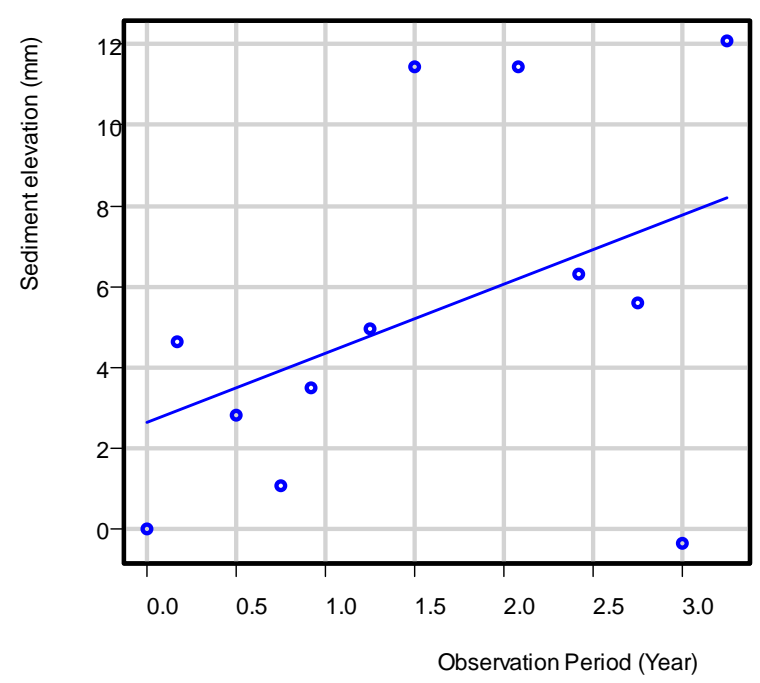

(b) 10-year-old

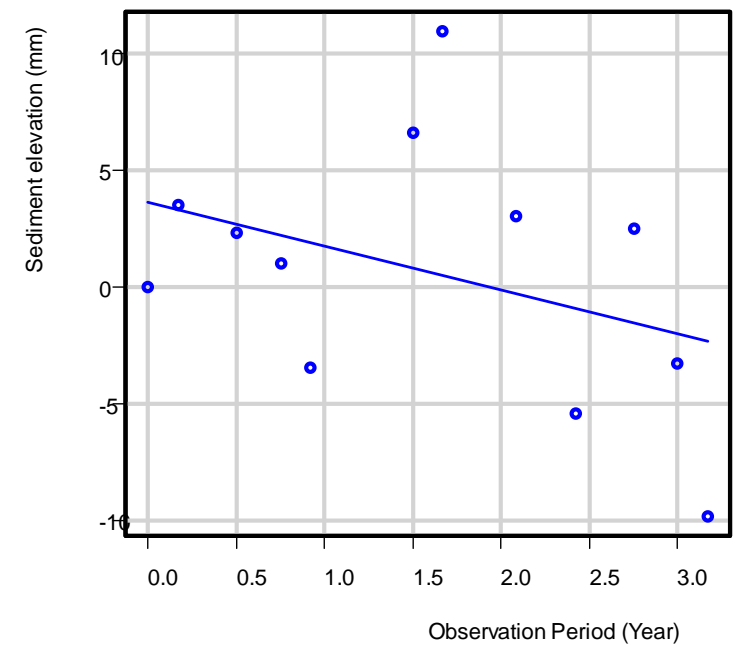

(d) Natural stand

Figure 2. Sediment surface elevation change in the 5-, 10-, and 25-year-old mangrove plantations and the reference natural mangrove stand, Quezon province.

Juxtaposing the elevation rates we measured with published rates of sea level rise reveals that rates of sediment elevation change from our older restored and natural sites are below the global rate $\left(3.2 \mathrm{~mm}_{\text {year }}{ }^{-1}\right)$ of sea level rise [37] and also below the sea level rise rate reported for north central Philippines, which is about $2-4 \mathrm{~mm}_{\text {year }}{ }^{-1}$ [38]. These values suggest that as restored sites increase in age, they may not be able to keep up with sea level rise and may potentially drown in the future, as flooding could result in tree, root, and rhizome death and an abrupt change in elevation through peat collapse $[29,39]$. This would create a positive feedback loop between sea level rise and elevation loss.

One caveat to the above results is the fact that we are ignoring how mangroves may respond to increased rates of SLR [40]. The mangroves we sampled in the Philippines exist in high tidal prisms that have greater elevation capital and thus accommodation space that could allow mangroves to survive and not immediately be lost to SLR [16,41,42]. Additional monitoring is needed to track this response. Regardless, pro-active solutions such as strict protection and hydrologic restoration must be made to increase the likelihood that these mangroves will survive. 


\subsection{Contemporary Soil C Sequestration Rates}

The mean soil carbon sequestration rates were $226.3 \pm 94 \mathrm{gC} \mathrm{m}^{-2}$ year $^{-1}$ for the 5-year-old plantation, and $123.6 \pm 95.7$ and $9 \pm 139 \mathrm{gC} \mathrm{m}^{-2}$ year $^{-1}$ for the 10-year-old and 25-year-old plantations, respectively (Table 4). On the other hand, the rate for the reference natural stand was $-94.5 \pm 37 \mathrm{gC} \mathrm{m}^{-2}$ year $^{-1}$, owing to loss of elevation over the study period of three years.

Table 4. Soil carbon sequestration rates in all four study sites (mean $\pm \mathrm{SE}$ ).

\begin{tabular}{cc}
\hline Stand Age & Soil C Sequestration Rate $\left(\mathbf{g C ~}^{-\mathbf{2}}\right.$ year $\left.^{-\mathbf{1}}\right)$ \\
\hline 5-year-old plantation & $226.3 \pm 94 \mathrm{a}$ \\
10-year-old plantation & $123.6 \pm 95 \mathrm{a}$ \\
25-year-old plantation & $9.0 \pm 139 \mathrm{a}$ \\
Natural Stand & $-94.5 \pm 37 \mathrm{a}$ \\
\hline
\end{tabular}

Different letters after the means indicate significant differences at $p<0.05$.

The rates of soil $\mathrm{C}$ sequestration we computed for the 5- and 10-year-old plantations were within the range reported by the literature, with a global range of $20-949 \mathrm{~g} \mathrm{C} \mathrm{m}^{-2}$ year $^{-1}$, although lower than the global mean of $163 \mathrm{~g} \mathrm{C} \mathrm{m}^{-2}$ year $^{-1}$ [13], and that the 25-year-old plantation and the natural stand were below. The rates for mangrove plantations, except the 25-year-old stand, are higher than the rate reported for coastal wetlands of Tinchi Tamba in western Moreton Bay, Queensland, Australia at about $30 \mathrm{~g} \mathrm{C} \mathrm{m}^{-2}$ year $^{-1}$ [13] but higher than the value reported for southern Australia at $105 \mathrm{~g} \mathrm{C} \mathrm{m}^{-2}$ year ${ }^{-1}$ [15].

The differences in rates could be due to differences in the sources of offsite carbon, below-ground productivity and rates of export [43], and the methods used to determine carbon sequestration rates (e.g., contemporary vs. long-term $C$ sequestration). Our C sequestration rate is considered contemporary, where the depth of soil we considered was at the upper $5 \mathrm{~cm}$ of the sediment that corresponds to $5-50$ years of accumulation [13]. As with the sediment elevation, the highly variable data and few replicates $(n=3)$ per age group could have been the reasons for the statistical non-significance between the means despite the data transformation.

\subsection{Relationship with Stand Variables}

In order to determine if there was a relationship between tree density, tree diversity, above-ground biomass, below-ground biomass, total biomass, basal area, and soil carbon stock and rates of sediment elevation change and soil carbon sequestration, the data were subjected to the Pearson product-moment correlation test. Table 5 also presents the aboveground, below-ground, and total biomass, as well as the basal area of the study sites.

Table 5. Summary of biomass, basal area, and soil C density values in the study sites (mean \pm SE).

\begin{tabular}{|c|c|c|c|c|c|}
\hline \multirow{2}{*}{ Study Site } & \multicolumn{3}{|c|}{ Biomass C Density (kg C ha $\left.{ }^{-1}\right)$} & \multirow{2}{*}{$\begin{array}{c}\text { Basal Area } \\
\left(\mathrm{m}^{2} \mathrm{ha}^{-1}\right)\end{array}$} & \multirow{2}{*}{$\begin{array}{c}\text { Soil C Stock } \\
\text { (tC/ha) }\end{array}$} \\
\hline & Above-Ground & Below-Ground & Total & & \\
\hline 5-year-old plantation & $3.13 \pm 0.4 \mathrm{a}$ & $1.98 \pm 0.2 \mathrm{a}$ & $5.11 \pm 0.6 \mathrm{a}$ & $0.84 \pm 0.1 \mathrm{a}$ & $533.3 \pm 19.2 \mathrm{a}$ \\
\hline 10-year-old plantation & $28.00 \pm 2.9 \mathrm{a}$ & $13.71 \pm 1.4 \mathrm{a}$ & $41.72 \pm 4.4 \mathrm{a}$ & $4.59 \pm 0.5 \mathrm{a}$ & $682.9 \pm 26.2 \mathrm{ab}$ \\
\hline 25-year-old plantation & $83.40 \pm 6.1 b$ & $24.27 \pm 9.9 a$ & $107.67 \pm 4.4 \mathrm{~b}$ & $11.07 \pm 0.8 \mathrm{~b}$ & $575.4 \pm 37.0 \mathrm{a}$ \\
\hline Natural Stand & $169.52 \pm 14.9 c$ & $77.76 \pm 6.3 b$ & $247.28 \pm 21.1 \mathrm{c}$ & $24.75 \pm 1.9 c$ & $814.6 \pm 73.4 b$ \\
\hline
\end{tabular}

Different letters after the means indicate significant differences at $p<0.05$.

For soil carbon stocks, a mean soil $\mathrm{C}$ stock of $814.6 \mathrm{t} \mathrm{C} \mathrm{ha}{ }^{-1}$ was computed for the natural mangrove, while it was $533.3 \mathrm{tC} \mathrm{ha}^{-1}$ for the 5-year-old plantation, and 682.9 and $575.4 \mathrm{t} \mathrm{C} \mathrm{ha}{ }^{-1}$, respectively, for the 10-year-old and 25-year-old plantation sites. It must be noted, however, that soil $\mathrm{C}$ stock was computed from only two plots in the 10-year-old plantation study site in Catanauan, and thus the mean soil C stock as well as the standard error for this study site is based on two replicates only. 
Based on the Pearson product-moment correlation test (Table 6), except for biomass and basal area, we obtained no significant relationships between the rate of sediment elevation change and the vegetation and soil variables $(p>0.05)$, as well as between the rate of soil carbon sequestration and the vegetation and soil variables $(p>0.05)$. The absence of linear relationships between the parameters studied suggest that the rates of sediment elevation change and soil $\mathrm{C}$ sequestration in natural and mangrove plantations in the study sites might not be predicted using the above auxiliary vegetation and soil variables.

Table 6. Summary table of Pearson product-moment correlation coefficients (r).

\begin{tabular}{ccccc}
\hline Stand Variables & \multicolumn{2}{c}{ Sediment Elevation Change Rate } & \multicolumn{2}{c}{ Soil Carbon Sequestration } \\
\hline & $\mathbf{R}$ & $\boldsymbol{p}$ & $\mathbf{r}$ & $\boldsymbol{p}$ \\
\hline Tree Density & -0.41 & $>0.05$ & -0.45 & $>0.05$ \\
Tree Diversity & -0.55 & $>0.05$ & -0.46 & $>0.05$ \\
Above-ground Biomass & -0.59 & $<0.05$ & -0.57 & $>0.05$ \\
Below-ground Biomass & -0.66 & $<0.05$ & -0.67 & $<0.05$ \\
Total Biomass & -0.63 & $<0.05$ & -0.62 & $<0.05$ \\
Basal Area & -0.60 & $<0.05$ & -0.58 & $<0.05$ \\
Soil Carbon Density & -0.40 & $>0.05$ & -0.30 & $>0.05$
\end{tabular}

This study has not fully established the long-term trend in the sediment elevation change rate given the data collection period of only three years. Additional years of monitoring are required to establish this longer term trend and to see if and how mangroves are responding to increased rates of SLR. Another limitation of this study is that the closest natural mangrove stand used as reference in this study is some $105 \mathrm{~km}$ away from the chrono-ages mangrove plantations. The chrono-ages mangroves and the reference natural mangrove are located in different bays and may have different sediment inputs and intensities of wave action.

Future studies should endeavor to select sites that are located in the same embayment. Finally, due to the absence of a local supply of feldspar, we were not able to pair the rSET with marker horizons so that the accretion rate and below-ground processes can be computed from the sediment elevation change. Future works, therefore, should explore other materials that can be used as marker horizons.

\section{Conclusions}

This study is the first attempt in the Philippines to monitor the vulnerability of mangroves in the country against the impact of sea level rise. The study demonstrated how well the mangroves studied in Quezon, Philippines are responding to sea level rise based on their rates of sediment surface elevation change, and how well they sequester contemporary Carbon in soil pool.

The study's findings provide new data on the rate of sediment elevation change of mangroves in the Philippines and demonstrate the usefulness of the rSET technique in quantifying the sediment elevation change of mangroves in Quezon province. Specifically, we found that younger stands of restored mangroves have greater rates of sediment elevation change and carbon accumulation. This suggests that these younger sites may be more resilient to SLR than older ones. It also provides us with evidence on how restoration returns $C$ stocks to degraded forests, through large inputs that occur early on in the restoration stage. Furthermore, old mangroves have bigger carbon stocks, whereas young mangrove plantations are more resilient to SLR and have higher contemporary carbon sequestration rates.

Continuous monitoring of the surface elevation change in these mangrove formations should be conducted to have more robust and long-term trends. In addition, establishing baseline data and monitoring the response to sea level rise of mangroves in other parts of the Philippines will provide us with the information needed to better understand how we might increase the resilience of Philippine mangroves to sea level rise impact. 


\begin{abstract}
Author Contributions: Conceptualization, J.A.C. and R.M.; methodology, J.A.C. and R.M.; formal analysis, J.A.C., R.M., J.R.M. and J.C.; data curation, J.A.C., R.M. and J.R.M.; writing-original draft preparation, J.A.C. and J.C.; writing-review and editing, J.A.C., R.M., J.R.M. and J.C.; funding acquisition, J.A.C. and J.C. All authors have read and agreed to the published version of the manuscript.

Funding: This research was funded by the ECOSYSTEMS RESEARCH AND DEVELOPMENT BUREAU of the Department of Environment and Natural Resources, PHILIPPINES and by United States Agency for International Development (USAID) under the Sustainable Wetlands Adaptation and Mitigation Program (SWAMP).
\end{abstract}

Acknowledgments: We wish to acknowledge the assistance given by Benjo Salvatiera, Liza Ranes, Mariche Bandibas, Noel Angelo Arboleda, and Rommel Mercado.

Conflicts of Interest: The authors declare no conflict of interest.

\title{
References
}

1. Alongi, D. The Energetics of Mangrove Forests; Springer Science \& Business Media: Berlin/Heidelberg, Germany, 2009.

2. Alongi, D. Carbon Cycling and Storage in Mangrove Forests. Annu. Rev. Mar. Sci. 2014, 6, 195-219. [CrossRef] [PubMed]

3. Clough, B. Continuing the Journey Amongst Mangroves; The International Society for Mangrove Ecosystems: Okinawa, Japan, 2013.

4. Chmura, G.; Anisfeld, S.; Cahoon, D.; Lynch, J. Global carbon sequestration in tidal, saline wetland soils. Glob. Biogeochem. Cycles 2003, 17. [CrossRef]

5. Donato, D.; Kauffman, J.; Murdiyarso, D.; Kurnianto, S.; Stidham, M.; Kanninen, M. Mangroves among the most carbon-rich forests in the tropics. Nat. Geosci. 2011, 4, 293-297. [CrossRef]

6. Murdiyarso, D.; Kauffman, J.; Verchot, L. Climate change mitigation strategies should include tropical wetlands. Carbon Manag. 2013, 4, 491-499. [CrossRef]

7. Pendleton, L.; Donato, D.; Murray, B.; Crooks, S.; Jenkins, W.; Sifleet, S.; Craft, C.; Fourqurean, J.; Kauffman, J.; Marbà, N.; et al. Estimating Global “Blue Carbon” Emissions from Conversion and Degradation of Vegetated Coastal Ecosystems. PLoS ONE 2012, 7, e43542. [CrossRef] [PubMed]

8. Primavera, J.; Esteban, J. A review of mangrove rehabilitation in the Philippines: Successes, failures and future prospects. Wetl. Ecol. Manag. 2008, 16, 345-358. [CrossRef]

9. Samson, M.; Rollon, R. Growth Performance of Planted Mangroves in the Philippines: Revisiting Forest Management Strategies. AMBIO J. Hum. Environ. 2008, 37, 234-240. [CrossRef]

10. MacKenzie, R.; Foulk, P.; Klump, J.; Weckerly, K.; Purbospito, J.; Murdiyarso, D.; Donato, D.; Nam, V. Sedimentation and belowground carbon accumulation rates in mangrove forests that differ in diversity and land use: A tale of two mangroves. Wetl. Ecol. Manag. 2016, 24, 245-261. [CrossRef]

11. Intergovernmental Panel on Climate Change. Climate Change 2013: The Physical Science Basis. Contribution of Working Group I to the Fifth Assessment Report of the Intergovernmental Panel on Climate Change; Stocker, T., Qin, D., Plattner, T., Allen, S., Boschung, N., Xia, B., Bex, M., Eds.; Cambridge University Press: Cambridge, UK; New York, NY, USA, 2013; p. 1535.

12. Krauss, K.; McKee, K.; Lovelock, C.; Cahoon, D.; Saintilan, N.; Reef, R.; Chen, L. How mangrove forests adjust to rising sea level. New Phytol. 2013, 202, 19-34. [CrossRef]

13. Lovelock, C.; Adame, M.; Bennion, V.; Hayes, M.; O’Mara, J.; Reef, R.; Santini, N. Contemporary Rates of Carbon Sequestration Through Vertical Accretion of Sediments in Mangrove Forests and Saltmarshes of South East Queensland, Australia. Estuaries Coasts 2013, 37, 763-771. [CrossRef]

14. Fu, H.; Wang, W.; Ma, W.; Wang, M. Differential in surface elevation change across mangrove forests in the intertidal zone. Estuar. Coast. Shelf Sci. 2018, 207, 203-208. [CrossRef]

15. Howe, A.; Rodríguez, J.; Saco, P. Surface evolution and carbon sequestration in disturbed and undisturbed wetland soils of the Hunter estuary, southeast Australia. Estuar. Coast. Shelf Sci. 2009, 84, 75-83. [CrossRef]

16. Lovelock, C.; Cahoon, D.; Friess, D.; Guntenspergen, G.; Krauss, K.; Reef, R.; Rogers, K.; Saunders, M.; Sidik, F.; Swales, A.; et al. The vulnerability of Indo-Pacific mangrove forests to sea-level rise. Nature 2015, 526, 559-563. [CrossRef] [PubMed]

17. Sasmito, S.; Murdiyarso, D.; Friess, D.; Kurnianto, S. Can mangroves keep pace with contemporary sea level rise? A global data review. Wetl. Ecol. Manag. 2015, 24, 263-278. [CrossRef]

18. Giri, C.; Ochieng, E.; Tieszen, L.; Zhu, Z.; Singh, A.; Loveland, T.; Masek, J.; Duke, N. Status and distribution of mangrove forests of the world using earth observation satellite data. Glob. Ecol. Biogeogr. 2010, 20, 154-159. [CrossRef]

19. Woodroffe, C.; Rogers, K.; McKee, K.; Lovelock, C.; Mendelssohn, I.; Saintilan, N. Mangrove Sedimentation and Response to Relative Sea-Level Rise. Annu. Rev. Mar. Sci. 2016, 8, 243-266. [CrossRef]

20. Howard, J.; Hoyt, S.; Isensee, K.; Telszewski, M.; Pidgeon, E. (Eds.) Coastal Blue Carbon: Methods for Assessing Carbon Stocks and Emissions Factors in Mangroves, Tidal Salt Marshes, and Seagrasses; Conservation International, Intergovernmental Oceanographic Commission of UNESCO, International Union for Conservation of Nature: Arlington, VA, USA, 2014.

21. Kauffman, J.; Donato, D. Protocols for the Measurement, Monitoring and Reporting of Structure, Biomass and Carbon Stocks in Mangrove Forests; Center for International Forestry Research: Bogor, Indonesia, 2012. 
22. Komiyama, A.; Poungparn, S.; Kato, S. Common allometric equations for estimating the tree weight of mangroves. J. Trop. Ecol. 2005, 21, 471-477. [CrossRef]

23. Adame, M.; Kauffman, J.; Medina, I.; Gamboa, J.; Torres, O.; Caamal, J.; Reza, M.; Herrera-Silveira, J. Carbon Stocks of Tropical Coastal Wetlands within the Karstic Landscape of the Mexican Caribbean. PLoS ONE 2013, 8, e56569. [CrossRef]

24. Kauffman, J.; Heider, C.; Norfolk, J.; Payton, F. Carbon stocks of natural mangroves and carbon emissions arising from their conversion in the Dominican Republic. Ecol. Appl. 2014, 24, 518-527. [CrossRef]

25. Kauffman, J.; Hernandez Trejo, H.; del Carmen Jesus Garcia, M.; Heider, C.; Contreras, W. Carbon stocks of mangroves and losses arising from their conversion to cattle pastures in the Pantanos de Centla, Mexico. Wetl. Ecol. Manag. 2015, 24, 203-216. [CrossRef]

26. Castillo, J.; Apan, A.; Maraseni, T.; Salmo, S. Tree biomass quantity, carbon stock and canopy correlates in mangrove forest and land uses that replaced mangroves in Honda Bay, Philippines. Reg. Stud. Mar. Sci. 2018, 24, 174-183. [CrossRef]

27. Lynch, J.; Hensel, P.; Cahoon, D. The Surface Elevation Table and Marker Horizon Technique: A Protocol for Monitoring Wetland Elevation Dynamics; Natural Resource Report NPS/NCBN/NRR—2015/1078; National Park Service: Fort Collins, CO, USA, 2015.

28. Osland, M.; Spivak, A.; Nestlerode, J.; Lessmann, J.; Almario, A.; Heitmuller, P.; Russell, M.; Krauss, K.; Alvarez, F.; Dantin, D.; et al. Ecosystem Development After Mangrove Wetland Creation: Plant-Soil Change Across a 20-Year Chronosequence. Ecosystems 2012, 15, 848-866. [CrossRef]

29. Krauss, K.; Cormier, N.; Osland, M.; Kirwan, M.; Stagg, C.; Nestlerode, J.; Russell, M.; From, A.; Spivak, A.; Dantin, D.; et al. Created mangrove wetlands store belowground carbon and surface elevation change enables them to adjust to sea-level rise. Sci. Rep. 2017, 7, 1030. [CrossRef] [PubMed]

30. Sharma, S.; MacKenzie, R.; Tieng, T.; Soben, K.; Tulyasuwan, N.; Resanond, A.; Blate, G.; Litton, C. The impacts of degradation, deforestation and restoration on mangrove ecosystem carbon stocks across Cambodia. Sci. Total Environ. 2020, 706, 135416. [CrossRef] [PubMed]

31. MacKenzie, R.; Sharma, S.; Rovai, A. Environmental drivers of blue carbon dynamics in mangrove forests. In Dynamic Sedimentary Environments of Mangrove Coasts; Sidik, F., Friess, D., Eds.; Elsevier Publishing: Amsterdam, The Netherlands, 2020.

32. Alongi, D.; Sasekumar, A.; Chong, V.; Pfitzner, J.; Trott, L.; Tirendi, F.; Dixon, P.; Brunskill, G. Sediment accumulation and organic material flux in a managed mangrove ecosystem: Estimates of land-ocean-atmosphere exchange in peninsular Malaysia. Mar. Geol. 2004, 208, 383-402. [CrossRef]

33. Marchand, C. Soil carbon stocks and burial rates along a mangrove forest chronosequence (French Guiana). For. Ecol. Manag. 2017, 384, 92-99. [CrossRef]

34. Krauss, K.; Cahoon, D.; Allen, J.; Ewel, K.; Lynch, J.; Cormier, N. Surface Elevation Change and Susceptibility of Different Mangrove Zones to Sea-Level Rise on Pacific High Islands of Micronesia. Ecosystems 2010, 13, 129-143. [CrossRef]

35. McKee, K.; Cahoon, D.; Feller, I. Caribbean mangroves adjust to rising sea level through biotic controls on change in soil elevation. Glob. Ecol. Biogeogr. 2007, 16, 545-556. [CrossRef]

36. Cahoon, D.; Hensel, P.; Rybczyk, J.; McKee, K.; Proffitt, C.; Perez, B. Mass tree mortality leads to mangrove peat collapse at Bay Islands, Honduras after Hurricane Mitch. J. Ecol. 2003, 91, 1093-1105. [CrossRef]

37. Merrifield, M.; Merrifield, S.; Mitchum, G. An Anomalous Recent Acceleration of Global Sea Level Rise. J. Clim. 2009, 22, 5772-5781. [CrossRef]

38. Kahana, R.; Abdon, R.; Daron, J.; Scannell, C. Projections of Mean Sea Level Change for the Philippines; Met Office: Devon, UK, 2016; p. 32.

39. Lang'at, J.; Kairo, J.; Mencuccini, M.; Bouillon, S.; Skov, M.; Waldron, S.; Huxham, M. Rapid Losses of Surface Elevation following Tree Girdling and Cutting in Tropical Mangroves. PLoS ONE 2014, 9, e107868. [CrossRef] [PubMed]

40. Buffington, K.; MacKenzie, R.; Carr, J.; Apwong, M.; Krauss, K.; Thorne, K. Mangrove Species' Response to Sea-Level Rise Across Pohnpei, Federated States of Micronesia; U.S. Geological Survey: Reston, VA, USA, 2021; 44p.

41. Kirwan, M.; Mudd, S. Response of salt-marsh carbon accumulation to climate change. Nature 2012, 489, 550-553. [CrossRef] [PubMed]

42. Rogers, K.; Kelleway, J.; Saintilan, N.; Megonigal, J.; Adams, J.; Holmquist, J.; Lu, M.; Schile-Beers, L.; Zawadzki, A.; Mazumder, D.; et al. Wetland carbon storage controlled by millennial-scale variation in relative sea-level rise. Nature 2019, 567, 91-95. [CrossRef] [PubMed]

43. Twilley, R.; Chen, R.; Hargis, T. Carbon sinks in mangroves and their implications to carbon budget of tropical coastal ecosystems. Water Air Soil Pollut. 1992, 64, 265-288. [CrossRef] 